\title{
Student Mental Model on Energy Concept in Elementary School Students
}

\author{
Moch Yusuf Efendi ${ }^{1}$, Tommy Tanu Wijaya ${ }^{2, *}$, Herliana $^{3}$, Mahmud Alpusari ${ }^{3}$, Neni Hermita ${ }^{3}$ \\ ${ }^{1}$ Department of Education and Human Potentials Development, National Dong Hwa University, Hualien, Taiwan, China \\ ${ }^{2}$ Department of Mathematics and Statistics, Guangxi Normal University, China \\ ${ }^{3}$ Program Studi Pendidikan Guru Sekolah Dasar, Universitas Riau, Indonesia
}

Received November 2, 2020; Revised December 10, 2020; Accepted December 30, 2020

\section{Cite This Paper in the following Citation Styles}

(a): [1] Moch Yusuf Efendi, Tommy Tanu Wijaya, Herliana, Mahmud Alpusari, Neni Hermita , "Student Mental Model on Energy Concept in Elementary School Students," Universal Journal of Educational Research, Vol. 8, No. 12B, pp. 8528 8535, 2020. DOI: 10.13189/ujer.2020.082663.

(b): Moch Yusuf Efendi, Tommy Tanu Wijaya, Herliana, Mahmud Alpusari, Neni Hermita (2020). Student Mental Model on Energy Concept in Elementary School Students. Universal Journal of Educational Research, 8(12B), 8528 - 8535. DOI: 10.13189/ujer.2020.082663.

Copyright $@ 2020$ by authors, all rights reserved. Authors agree that this article remains permanently open access under the terms of the Creative Commons Attribution License 4.0 International License

\begin{abstract}
This study aims to identify students' mental models on each energy concept. Descriptive quantitative methods were used to get an overview of students' mental models related to the concept of energy. The sample of this study was grade IV students at SD Muhammadiyah 6 Pekanbaru. The instrument used to collect data was a conceptual understanding level test consisting of three question sections asking for answers in explanations and depictions. Students' mental models related to each energy concept reached the three categories of mental models determined: Scientific, Synthetic, and Initials. The mental model of students in the Scientific category is $5.77 \%$ in the energy concept of changing energy forms, the lowest Synthetic category is $11.1 \%$ in the concept of energy benefits, and the highest Initials category is $88.46 \%$ in the concept of energy utilization in daily life. These results indicate that students understand the concept of energy based on daily experiences without using appropriate concepts. Students have not built on the knowledge gained during the learning process, and their answers are not correctly coherent.
\end{abstract}

Keywords Elementary Students' Mental Models, Energy Concepts

\section{Introduction}

Education aims to educate the nation's life. Education plays a role in the student's self-development process through the learning stage. Learning is essentially a process of interaction that takes place in an educational situation to achieve learning goals. Learning carried out in a home, or school environment will impact students' attitudes (character) and mental [1]-[6] School as a learning organization has an essential role in guiding students to reach a development level by optimizing developmental tasks. In the formation of learning organizations, schools must be able to encourage five core things, namely: 1) Systems Thinking, 2) Personal Skills (Personal Mastery), 3) Mental Model, 4) Shared Vision (Building Shared Vision), and 5) Team Learning (Team Learning) [3]. Of the five components, mental models have an essential role in schools to improve learning quality [2], [4]. Because mental models can inform how students understand, learn, remember, and think about information. The mental model in question is the structure of knowledge constructed by students to understand and explain their experiences of a concept.

Mental models, which are personal representations of student experiences, need to be known and explored to improve learning. The mental model of students needs to be known by teachers based on two reasons, namely: first, because mental models play a role in influencing students' cognitive function, and second, mental models can provide information about the framework concepts that students have. Students' mental models are influenced by several factors, which are group into six, namely: teacher 
explanations, textbooks, language and words, daily life experiences, social environment, and causal and intuition relationships [2].

In following the classroom's learning process, students are not like blank paper, but they already have an initial conception obtained through interaction with the environment, which is different from other students' concepts. Under the opinion of which states that each concept has a clear scientific description and has been agreed upon by scientists, but the representation of students, students, teachers, and lecturers will be different [7]. The representation in question is to express the knowledge in students' minds using language or words [8]. The use of language in conveying something to others is the main thing of representation [9]. Representation is related to students' mental models because it can provide an overview of how students process information to solve a problem [10].

Each individual's mental models, both students, and teachers, are not fixed and vary [11]. As shown in several previous studies ranging from students to students, such as the following, the research conducted aims to determine the Level or Level of mental models possessed by prospective teachers on conception material. This study indicates that many respondents are still at level 1 mental models because of prospective physics teachers answering questions only based on intuition and daily experience without using appropriate concepts. Meanwhile, students' mental models related to the concept of day and night showed that most students were only able to reach the moderate mental model category. Students' understanding is at the macroscopic representation level, and students cannot explain a phenomenon's causes [12]-[21]Thus, it explains that each individual's mental model is different in Level. Thus, it is necessary to find out the mental models that students have to make and continue developing in the learning process. In this study, the researcher's material was the concept of energy, one of the concepts taught in class IV elementary school in the 2013 curriculum. This study aims to determine the description of students' mental models in each energy-related concept.

\section{Materials and Methods}

This research is a quantitative method [22]. The instrument for collecting data in this study consisted of a conceptual understanding level test related to the concept of energy (table 1). Each test item consisted of three question parts, two questions requiring a verbal explanation response, and one question requiring a descriptive response in image representation. The conceptual level of the understanding test is to identify students' mental models regarding energy and parts. The number of items on the conceptual understanding test is four items, each related to the concept of energy sources, alternative energy, changes in energy forms, and energy use in everyday life.

Table 1. Grid of Related Conceptual Understanding Level Test Instruments

Every Energy Concept

\begin{tabular}{|c|c|c|c|}
\hline Basic competencies & Concept & $\begin{array}{c}\text { Test Item Indicator } \\
\end{array}$ & Number \\
\hline \multirow{4}{*}{$\begin{array}{l}\text { Identifying various } \\
\text { energy sources, changing } \\
\text { forms of energy, and } \\
\text { alternative energy } \\
\text { sources (wind, water, } \\
\text { solar, geothermal, } \\
\text { organic fuels dan } \\
\text { nuclear) in life. }\end{array}$} & Energy sources & $\begin{array}{ll}\text { A. } & \text { Explain the meaning of energy sources } \\
\text { B. Describe the photosynthetic process that involves solar energy } \\
\text { sources }\end{array}$ & 1 \\
\hline & $\begin{array}{c}\text { Alternative Energy } \\
\text { Sources }\end{array}$ & $\begin{array}{ll}\text { A. } & \text { Explain the meaning of alternative energy } \\
\text { B. Explain the role of alternative energy as substitute energy in } \\
\text { everyday life } \\
\text { C. Describe (pictures, tables, or graphs) examples of alternative } \\
\text { energy and their utilization }\end{array}$ & 2 \\
\hline & $\begin{array}{c}\text { Change in Energy } \\
\text { Form }\end{array}$ & $\begin{array}{l}\text { A. Explain the meaning of changing energy forms } \\
\text { A. Describe the changes in the form of energy that occur in } \\
\text { examples of everyday life } \\
\text { B. Describe (pictures, tables, or graphs) examples of changes in } \\
\text { energy in everyday life. }\end{array}$ & 3 \\
\hline & Energy Benefits & $\begin{array}{l}\text { A. Describe various examples of the use of energy sources } \\
\text { B. Describe the process of utilizing energy sources related to } \\
\text { examples in everyday life } \\
\text { C. Describe (pictures, tables, or graphs) the process of utilizing } \\
\text { energy sources by humans }\end{array}$ & 4 \\
\hline
\end{tabular}


Science learning for students is fundamental for students' and teachers' involvement in the learning process to achieve maximum results, with this seen from students' critical thinking skills. Critical thinking skills are to explore thinking, analytical in solving problems, and evaluating the problem. It is indispensable to educate children who are adaptable and ready to change, be critical and think creatively, and find solutions to any problems that arise and guarantee humanity. Critical thinking is judged by how a person considers and participates in the world to judge based on evidence and argumentation to decide decision making. Critical development and general thinking skills are the main goals of natural education learning. Critical thinking can be a way to develop knowledge that is already in the minds of students. Through critical thinking can improve students' thinking related to natural knowledge. The raw material in science (Natural Sciences) lessons in grade four elementary school is natural material resources. Material discusses and learns about the student's environment, types of natural resources, technology for exploiting natural resources, and various other things. Through subject matter related to everyday life, students will be able to apply their knowledge firsthand. The learning process with learning materials can develop 21st-century skills such as critical thinking skills, creativity, communication, problem-solving, and collaboration.

Furthermore, the test instrument's response to students evaluates giving a score according to the student's response description and visual response. The scoring technique refers to rubric at table 2 and table 3 to determine the problem-solving achievement level to a concept [23].

After the student's answers are evaluated using descriptive evaluation rubrics and visual evaluation rubrics and data related to student understanding, they obtain Students' mental model categories are determined referring to the categories presented in table 4 .

Data from the analysis of students' mental models' level of understanding and categories presented and discussed can use tables or graphs related to students' percentage level and mental models on each energy concept. The research results' discussion is an in-depth explanation and interpretation of the data presented.

Table 2. Grid of Related Conceptual Understanding Level Test Instruments

Every Energy Concept

\begin{tabular}{|c|c|c|}
\hline Comprehension level & Score & Criteria \\
\hline Sound Understanding (S.U.) & 4 & $\begin{array}{c}\text { Answers that contain all the components of a scientifically accepted } \\
\text { response }\end{array}$ \\
\hline Partial Understanding $(\mathrm{PU})$ & 3 & $\begin{array}{l}\text { Answers that contain several components of a scientifically } \\
\text { accepted response }\end{array}$ \\
\hline $\begin{array}{l}\text { Partial Understanding with Alternative } \\
\text { Conception (PU-AC) }\end{array}$ & 2 & $\begin{array}{l}\text { The answer shows that the concept is understood but also contains } \\
\text { other conceptions }\end{array}$ \\
\hline Alternative Conception (A.C.) & 1 & $\begin{array}{l}\text { Wrong answers are scientifically and contain nonsense or incorrect } \\
\text { information }\end{array}$ \\
\hline No Understanding (NU) & 0 & The response is blank, irrelevant, or unclear \\
\hline
\end{tabular}

Table 3. Evaluation Rubric for Visual Response

\begin{tabular}{|c|c|c|}
\hline Comprehension level & Score & Criteria \\
\hline Correct Depicting (CD) & 4 & An image that reflects all the components of a scientific depiction \\
\hline $\begin{array}{c}\text { Partial Correct Depicting (PCD) } \\
\text { Correct Drawings also reflecting Nonscientific } \\
\text { Depicting (CD-ND) }\end{array}$ & 2 & Images that reflect some of the components of scientific depiction \\
\hline Incorrect Depicting (ID) & 1 & $\begin{array}{c}\text { Images that reflect scientific depictions or depictions that are not } \\
\text { scientific (misrepresentation) }\end{array}$ \\
\hline No Depicting (ND) & 0 & An image that reflects an entirely unscientific depiction \\
\hline
\end{tabular}

Table 4. Students' Mental Model Category

\begin{tabular}{|c|c|c|}
\hline Mental Model Category & Content & Score For Each Question Section \\
\hline Scientific & $\begin{array}{c}\text { Students' perceptions coincide or match and can be } \\
\text { accepted scientifically. Level 3 (P.U. or PCD) and Level 4 } \\
\text { (S.U. or CD) }\end{array}$ & $\begin{array}{c}\text { The scores for questions A, B, and C are all } \\
\text { high (3 or 4) with no score below 3 }\end{array}$ \\
\hline Synthetic & $\begin{array}{c}\text { Students' perceptions are partly coincident with or } \\
\text { appropriate and partly unacceptable scientifically—all } \\
\text { possibilities at a level. }\end{array}$ & $\begin{array}{c}\text { The scores for questions A, B, and C are } \\
\text { mostly high (3 or 4) but partly low (0 or 1 or } \\
\text { 2) }\end{array}$ \\
\hline Initial & $\begin{array}{c}\text { Students' perceptions are unacceptable or scientifically } \\
\text { inappropriate. Level 0 (N.U. or N.D.), Level 1 (A.C. or } \\
\text { I.D.), and Level 2 (PU-AC or CD-ND). }\end{array}$ & $\begin{array}{c}\text { The scores for questions A, B, and C are all } \\
\text { low or under 3 (can be 0 or 1 or 2) }\end{array}$ \\
\hline
\end{tabular}




\section{Results and Discussion}

Based on the conceptual understanding level test results for 52 fourth grade students, data are obtained on the level of student conceptual understanding and the category of mental models that students had on each concept in the Energy material (see table 5).

As shown in Table 5, the conceptual understanding level test carried out related to energy; only on the concept of energy change students could achieve the three categories of mental models. In the concept of energy, sources students have not been able to reach the scientific mental model category, and in general, students are in the initial mental model category (80.77\%), meaning that in providing descriptive and visual responses, students' answers related to the concept of energy sources cannot be accepted or do not coincide scientifically. An example of a student's answer to the concept of energy sources belonging to the synthetic category is as figure 1 .

Figure 1 shows students' descriptive and visual responses to the concept of energy sources belonging to the synthetic category and at the level of understanding
P.U., PU-AC, and CD-ND. Furthermore, in the concept of alternative energy, students were also dominated by the initial mental model category (73.08\%). More than half of the students have not provided appropriate and acceptable descriptive and visual responses related to the concept of alternative energy. In the mental model category, the students' initials are at the level of understanding (N.U. or N.D.), (A.C. or I.D.), and (PU-AC or CD-ND). An example of student responses to the concept of alternative energy belonging to the initial category is as figure 2 .

Figure 2 descriptive and visual response of students to the concept of alternative energy belongs to the initial category and is at the level of understanding PU-AC, PU-AC, and CD-ND. In the concept of changing the form of energy, students were able to reach the mental model category, (5.77\%) students with the scientific category, (42.31\%) students with the synthetic category, and (51.92\%) students with the initial mental model category. In this concept, students can provide descriptions and visuals that coincide scientifically with the concept of changing the form of energy, even though more than half of the students are still in the initial category.

Table 5. Percentage of Students' Mental Model Categories in Each Energy Concept

\begin{tabular}{|c|c|c|c|c|c|c|c|c|}
\hline \multirow{3}{*}{$\begin{array}{c}\begin{array}{c}\text { Mental Model } \\
\text { Category }\end{array} \\
\text { Scientific }\end{array}$} & \multicolumn{8}{|c|}{ Energy Concept } \\
\hline & \multicolumn{2}{|c|}{$\begin{array}{c}1 \\
\text { Energy sources } \\
\end{array}$} & \multicolumn{2}{|c|}{$\begin{array}{c}2 \\
\text { Alternative Energy } \\
\end{array}$} & \multicolumn{2}{|c|}{$\begin{array}{c}3 \\
\text { Change in Energy Form }\end{array}$} & \multicolumn{2}{|c|}{$\begin{array}{c}4 \\
\text { Energy Benefits } \\
\end{array}$} \\
\hline & 0 & $0 \%$ & 0 & $0 \%$ & 3 & $5.77 \%$ & 0 & $0 \%$ \\
\hline Synthetic & 0 & $19.23 \%$ & 14 & $26.92 \%$ & 22 & $42.31 \%$ & 6 & $11.54 \%$ \\
\hline Initial & 42 & $80.77 \%$ & 38 & $73.08 \%$ & 27 & $51.92 \%$ & 46 & $88.46 \%$ \\
\hline Total & 52 & $100 \%$ & 52 & $100 \%$ & 52 & $100 \%$ & 52 & $100 \%$ \\
\hline
\end{tabular}

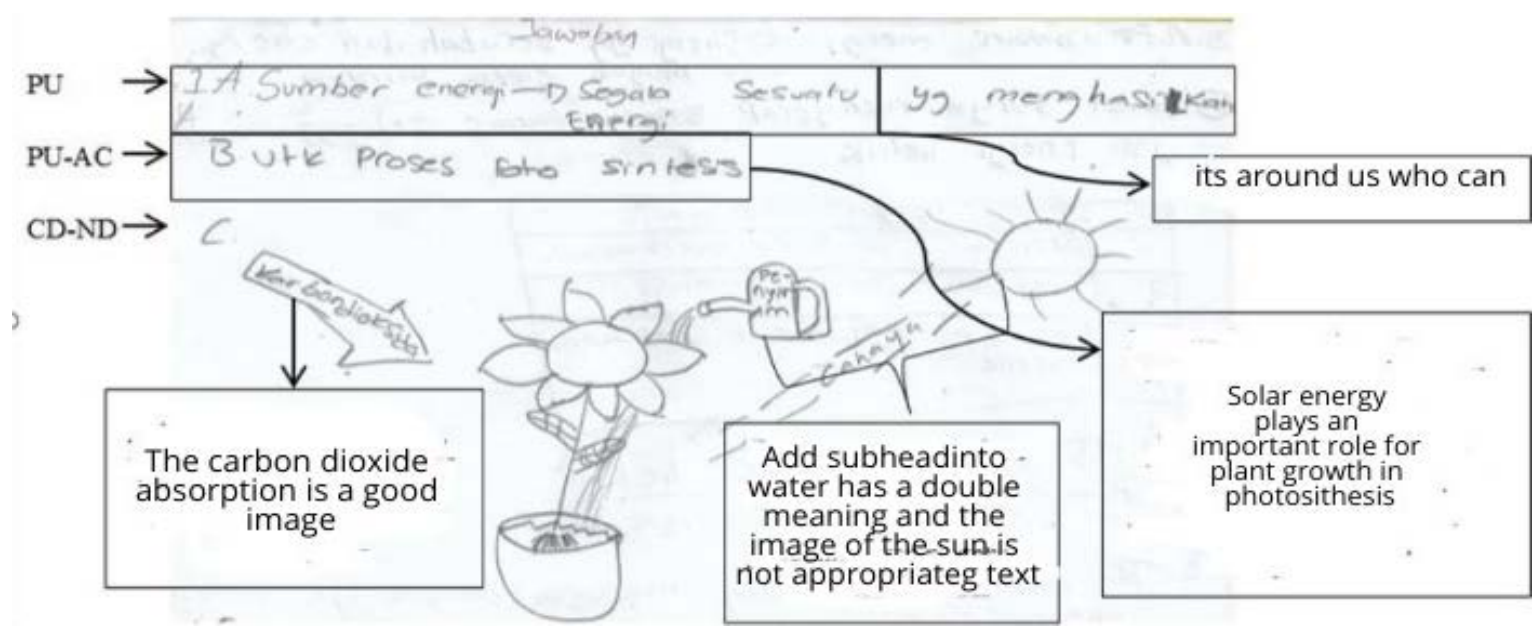

Figure 1. Student Answers to the Concept of Energy Sources in the Synthetic Category 


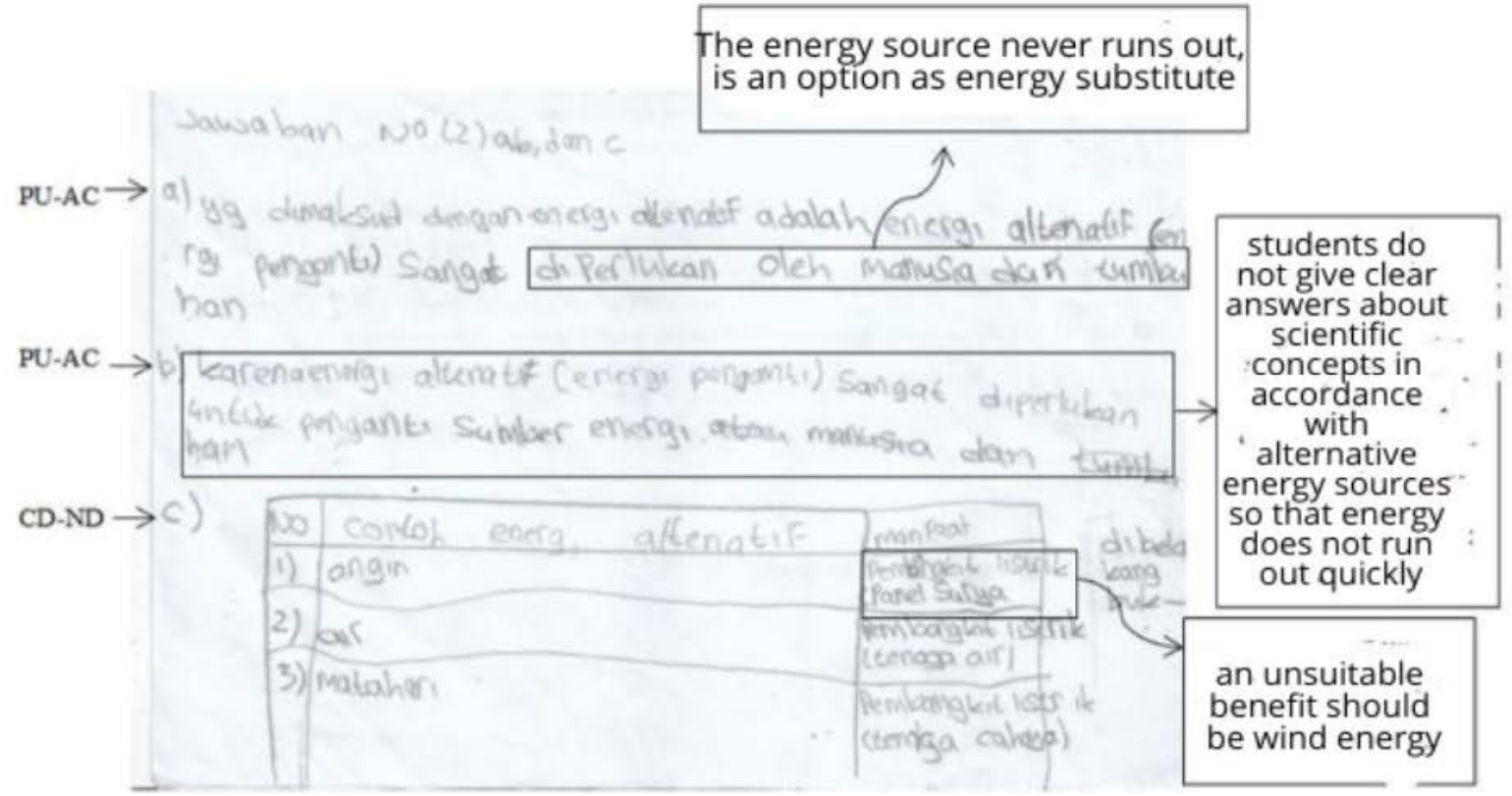

Figure 2. Student Answers to the Concept of Alternative Energy in the Initials Category

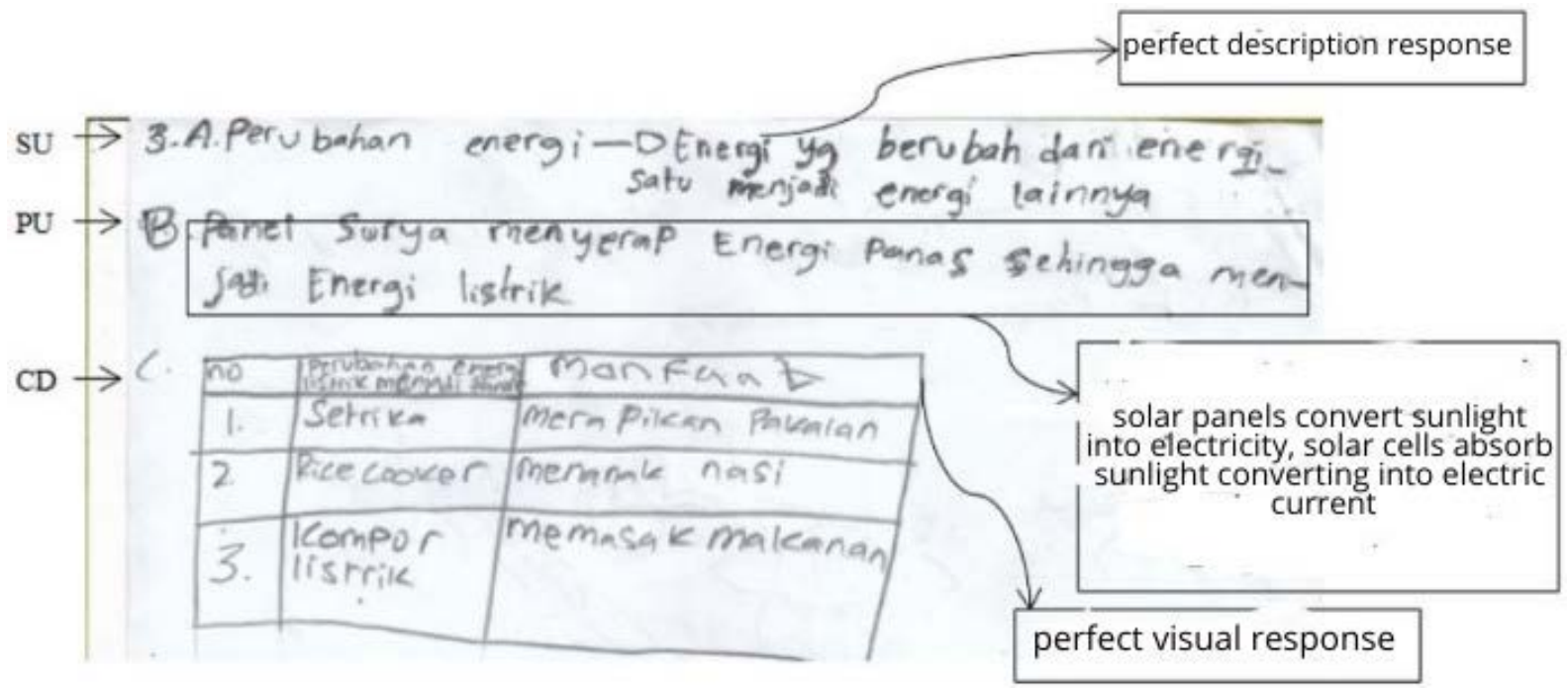

Figure 3. Student Answers to the Concept of Change in Energy Forms in the Scientific Category

Figure 3 shows students' descriptive and visual responses to the concept of changing the form of energy that belongs to the scientific category because it is at the level of understanding S.U., PU, and CD. Furthermore, most students could not provide descriptive and visual responses related to the concept of the benefits of energy, so they were in the initial mental model category (88.46\%).

Figure 4 shows the descriptive and visual student responses to the concept of the benefits of energy belonging to the synthetic category and at the level of understanding PU-AC, A.C., and CD. Based on the description above, the number of students in each concept's initial mental model category proves that students cannot fully understand the learning process's material. The classroom's learning process has not facilitated the achievement of the scientific mental model category (scientific) in students. Students' verbal explain or descript knowledge formed from real-world experiences or daily life. This analysis results are in line with the findings of related research that students' difficulties in understanding abstract concepts can be caused by everyday experiences that do not support solving problems involving more complex phenomena [24]-[26]. Meanwhile, based on the previous explanation, mental models can be formed or influenced by various factors grouped into six: teacher explanations, textbooks, language and words, daily life experiences, social environment, and causal and intuition relationships [27]. 


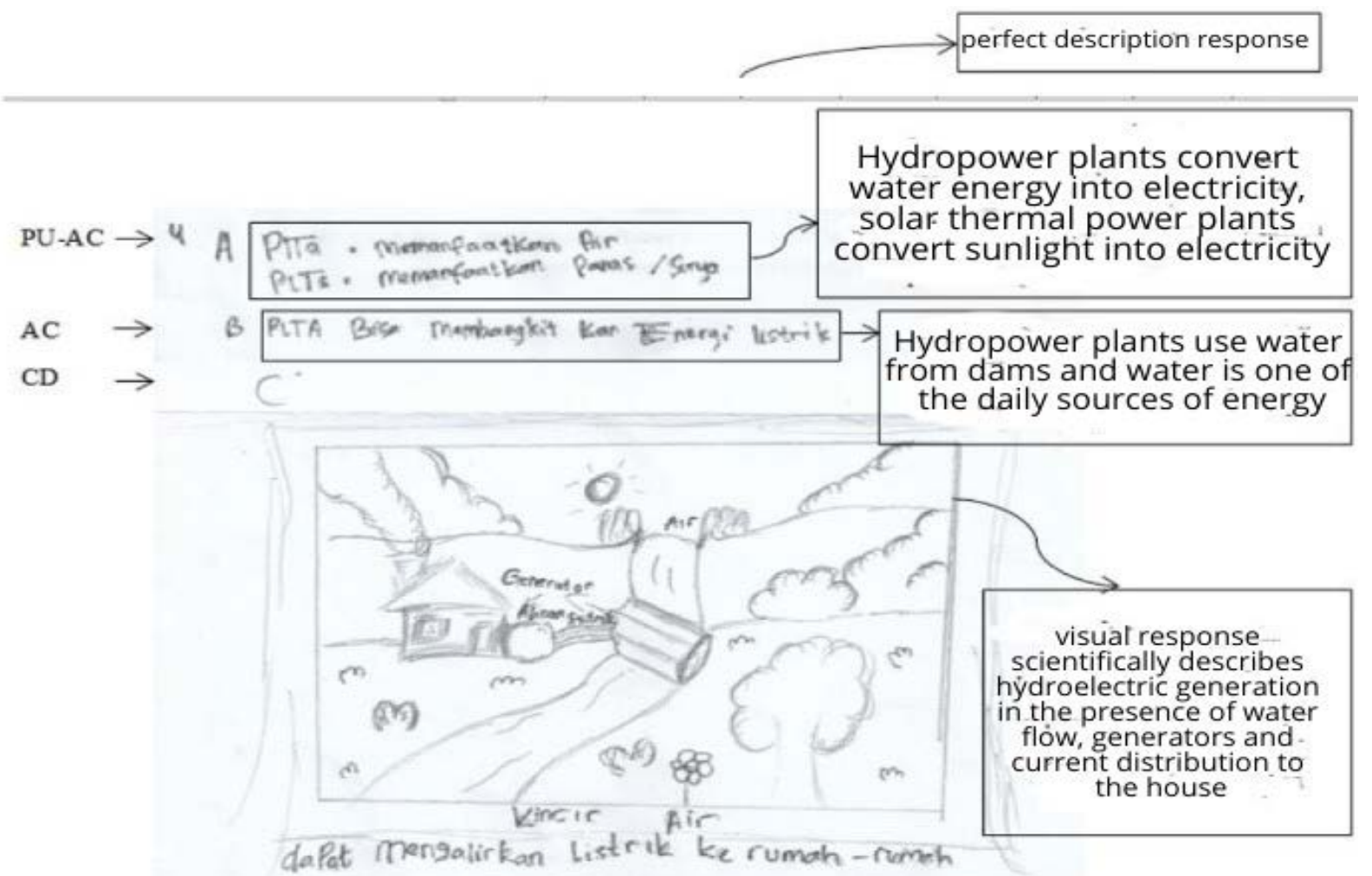

Figure 4. Student Answers to the Concept of Energy Benefits in the Synthetic Category

Teacher explanations and appropriate learning methods influence the construction of students' mental models because mental models can undergo changes and improvements through new information that is filtered and stored by students. Besides, textbooks or teaching materials used in the learning process also greatly affect students' mental models. It proves the percentage of students' mental models which are dominated by the initial or initial mental model categories because, in the observation activities, the researcher found that students in the learning process only focused on teaching materials in the form of integrated thematic books in the 2013 curriculum which contained concise material. Students are in a wrong understanding or even wrong in the initial category or do not coincide with scientific concepts (misconceptions) [28]. The cause of misconceptions or errors in understanding the concept is due to the lack of information obtained by students regarding the concept [29], [30]. So that if the teacher in the learning process cannot be a good facilitator, it is likely that students do not understand the concepts taught, one of the characteristics of mental models is synthetic, meaning that the mental model changes and continues to modify according to new information obtained. Thus, it is necessary to have an awareness of teachers in making decisions or looking for new ways in the learning process, by understanding what is happening through the description of mental models that students have. Because in learning, students are require to master knowledge, facts, and concepts about the material so that the mental model is entirely formed so that meaningful learning is achieved.

The limited ability of students in understanding each energy concept, misconceptions are influenced by abstract concepts that need to be presented with real examples by the teacher, using visual or audio-visual media to help students better understand concepts and be able to construct their knowledge to achieve the model mental scientific or scientific student mental model research results. In the learning process, he recommends learning that involves real examples and involves cognitive activities through discussion and interpretation to improve students' mental models.

The mental model profile of students in each concept still needs to be improved, because of the 52 grade IV students of SD Muhammadiyah 6 Pekanbaru, very few students were able to reach the category of scientific mental models. To improve students 'mental models, teachers must first pay attention to the origin of students' difficulties in building an understanding of a concept. Remembering the mental model is a description of the concepts that exist in students' minds and contribute the cognitive development of students in the learning process.

\section{Conclusions}

The fourth-grade students of SD Muhammadiyah 6 
Pekanbaru have three categories of mental models that are determined, namely scientific mental models, synthetic mental models, and initial mental models. None of the students achieved the category of scientific mental models on the concept of energy sources, alternative energy, and energy utilization. Most of the students are in the initial (initial) mental model category.

The percentage of the mental model profiles of students, the learning process in the classroom has not been able to facilitate the achievement of the scientific mental model category (scientific) in students. In answering questions, students can only provide verbal explanations or depictions based on knowledge formed from experiences in real life or everyday life so that they are not following scientific concepts.

\section{Acknowledgements}

The author would like to thank Guangxi Normal University, Guilin, China and the PGSD FKIP Universitas Riau, Indonesia for being allowed to carry out collaborative research and publications.

\section{REFERENCES}

[1] N. Hermita, M. Alpusari, E. Noviana, Z. H. Putra, N. Islami, H. Basori, A. Suhandi and A. Samsudin, "Improving prospective primary school teachers' mental models through implementation of CdOI supported by multimode visualization,” Univers. J. Educ. Res., vol. 8, no. 2, 2020, doi: 10.13189/ujer.2020.080217.

[2] T. A. Parlina, N. Hermita, M. Alpusari and E. Noviana, "Identifying Pupils' Mental Model of the Day and Night Concept," J. Teach. Learn. Elem. Educ., 2019, doi: 10.33578/jtlee.v2i2.7573.

[3] N. Hermita, T. A. Parlina, Z. H. Putra, M. Alpusari, J. A. Alim, I. K. Sari, E. A. Mulyani, R. A. Putra, K. Mahbubah, S. Anggoro and A. Suhandi, "Identifying of elementary students' mental model on gravity concept,” Int. J. Adv. Sci. Technol., vol. 29, no. 5, pp. 6772-6780, 2020.

[4] N. Hermita, M. Alpusari, E. Noviana, O. Kurniaman and N. Islami, "Profile of prospective primary school teachers' mental model in the subject matter of change," 2020, doi: 10.1088/1742-6596/1521/4/042096.

[5] A. Suhandi, A. Samsudin, E. Suhendi, N. Hermita, E. N. Syamsiah and B. Costu, "Facilitating conceptual changes of high school students regarding concepts in static electricity and DC circuits through the use of VMSCDCCText," Univers. J. Educ. Res., vol. 8, no. 3, 2020, doi: 10.13189/ujer.2020.080312.

[6] E. Syaodih, A. Suhandi, B. Maftuh, N. Hermita, N. J. Fratiwi and A. Samsudin, "Development and implementation of creative, solutive and smart teaching (CS2T) to improve $21^{\text {st }}$ century capability on wave and optics," in Journal of
Physics: Conference Series, 2019, vol. 1280, no. 5, doi: 10.1088/1742-6596/1280/5/052051.

[7] M. Tamur, D. Juandi and Y. S. Kusumah, "The Effectiveness of the Application of Mathematical Software in Indonesia; A Meta-Analysis Study,” Int. J. Instr., vol. 13, no. 4, pp. 867-884, 2020, doi: 10.29333/iji.2020.13453a.

[8] D. Juandi and A. Jupri, "Developing Mathematical Communication and Representation of Students Grade Vii: a Design Research,” J. Pengajaran Mat. dan Ilmu Pengetah. Alam, vol. 18, no. 2, p. 135, 2013, doi: 10.18269/jpmipa.v18i2.1.

[9] N. Idris and N. Mohd, "Mathematical creativity: usage of technology,” Procedia Soc. Behav. Sci., vol. 2, no. 2, pp. 1963-1967, 2010, doi: 10.1016/j.sbspro.2010.03.264.

[10] A. Wijayanti, Y. S. Kusumah and Suhendra, "How to Solve Polyhedron Problem?,” J. Phys. Conf. Ser., vol. 895, no. 1, 2017, doi: 10.1088/1742-6596/895/1/012070.

[11] A. Flores, J. Park and S. A. Bernhardt, "Interactive Technology to Foster Creativity in Future Mathematics Teachers," in Creativity and Technology in Mathematics Education, Springer International Publishing AG, 2018, pp. 149-179.

[12] A. R. Ningsih, R. N. Afifah, Qonita, Y. Gumala, H. Handayani, A. Suhandi, E. Syaodih, B. Maftuh, N. Hermita and A. Samsudin, "A preliminary study: How is extent the fourth-grade students understanding of the magnetic force?," in Journal of Physics: Conference Series, 2019, vol. 1280, no. 5, doi: 10.1088/1742-6596/1280/5/052048.

[13] Y. Gumala, A. Suhandi, E. Syaodih, B. Maftuh, N. Hermita and A. Samsudin, "Facilitating of fourth grade students problem solving skills on gravity," in Journal of Physics: Conference Series, 2019, vol. 1157, no. 3, doi: 10.1088/1742-6596/1157/3/032041.

[14] N. Hermita, A. Suhandi, E. Syaodih, A. Samsudin, Isjoni and F. Rosa, “Assessing pre-service elementary school teachers' alternative conceptions through a four-tier diagnostic test on magnetism concepts,” Adv. Sci. Lett., vol. 23, no. 11, 2017, doi: 10.1166/asl.2017.10184.

[15] E. Syaodih, L. Kurniawati, H. Handayani, D. Setiawan, I. Suhendra and N. Hermita, "Critical Thinking Skills of Fifth Grade Elementary School Students in Bandung City on the Topic of Water Cycle in Natural Science Subjects," in Journal of Physics: Conference Series, 2019, vol. 1351, no. 1, doi: 10.1088/1742-6596/1351/1/012073.

[16] A. R. Ningsih, A. Suhandi, E. Syaodih, B. Maftuh, N. Hermita and A. Samsudin, "Fourth-grade elementary students critical thinking skills: A preliminary study on magnetic force," in Journal of Physics: Conference Series, 2019, vol. 1157, no. 3, doi: 10.1088/1742-6596/1157/3/032 045 .

[17] N. Hermita, A. Suhandi, E. Syaodih, A. Samsudin, W. Sopandi, M. Muslim, F. C. Wibowo, B. Maftuh, Z. K. Prasetyo, M. N. Mustafa, I. Isjoni, H. Marhadi, F. Rosa, S. Sumardi and B. Costu, "The effectiveness of using virtual simulation and analogy in the conceptual change oriented-physics learning on direct current circuits,” Turkish Online J. Educ. Technol., vol. 2017, no. December Special Issue INTE, 2017. 
[18] R. N. Afifah, E. Syaodih, A. Suhandi, B. Maftuh, N. Hermita, H. Handayani, Qonita, A. R. Ningsih, Y. Gumala and A. Samsudin, "Develop children's science process skills through building activities in center of beam: Optical geometry on focus," in Journal of Physics: Conference Series, 2019, vol. 1280, no. 5, doi: 10.1088/1742-6596/128 0/5/052016.

[19] F. C. Wibowo, A. Suhandi, A. Samsudin, D. R. Darman, J. Akbardin, N. Hermita, Supriyatman, D. Rusdiana, Nahadi and B. Coştu, "Contribution of virtual microscopic simulation (Vms) to unveil students' conceptual development and misconceptions of physics concepts of heat transfer,” Turkish Online J. Educ. Technol., vol. 2017, no. Special Issue 2017, 2017.

[20] A. Samsudin, N. J. Fratiwi, I. Kaniawati, E. Suhendi, N. Hermita, A. Suhandi, F. C. Wibowo, B. Coştu, J. Akbardin and S. Supriyatman, “Alleviating students' misconceptions about newton's first law through comparing pdeode*E tasks and poe tasks: Which is more effective?," Turkish Online J. Educ. Technol., vol. 2017, no. October Special Issue INTE, 2017.

[21] A. Samsudin, A. Suhandi, D. Rusdiana, I. Kaniawati, N. J. Fratiwi, A. Zulfikar, M. H. Muhaemin, N. Hermita, Mansur, F. C. Wibowo, Supriyatman, A. Malik and B. Costu, “Optimizing Students' Conceptual Understanding on Electricity and Magnetism through Cognitive Conflict-Based Multimode Teaching (CC-BMT)," in Journal of Physics: Conference Series, 2019, vol. 1204, no. 1, doi: 10.1088/1742-6596/1204/1/012027.

[22] S. Chotimah, T. T. Wijaya, E. Aprianti, P. Akbar and M. Bernard, "Increasing primary school students ' reasoning ability on the topic of plane geometry by using hawgent dynamic mathematics software Increasing primary school students ' reasoning ability on the topic of plane geometry by using hawgent dynamic mathematics,” J. Phys. Conf. Ser., vol. 1657, no. 1, p. 012009, 2020, doi: 10.1088/1742-6596/1657/1/012009.

[23] Zulfah, Astuti, Y. F. Surya, R. Marta and T. T. Wijaya,
"Measurement of mathematics problems solving ability using problem based mathematics question," in Journal of Physics: Conference Series, 2020, vol. 1613, no. 1, doi: 10.1088/1742-6596/1613/1/012026.

[24] Zulfah, Astuti, Y. F. Surya, R. Marta and T. T. Wijaya, "Measurement of mathematics problems solving ability using problem based mathematics question Measurement of mathematics problems solving ability using problem based mathematics question,” J. Phys. Conf. Ser., vol. 1613, no. 1, 2020, doi: 10.1088/1742-6596/1613/1/012026.

[25] L. Zhang, Y. Zhou and T. T. Wijaya, "Hawgent dynamic mathematics software to improve problem-solving ability in teaching triangles,” J. Phys. Conf. Ser., vol. 1663, no. 1, 2020, doi: 10.1088/1742-6596/1663/1/012069.

[26] T. T. Wijaya, Z. Ying, S. Chotimah, M. Bernard, Z. Zulfah and A. Astuti, "Hawgent dynamic mathematic software as mathematics learning media for teaching quadratic functions,” J. Phys. Conf. Ser., vol. 1592, no. 1, 2020, doi: 10.1088/1742-6596/1592/1/012079.

[27] S. Chatmaneerungcharoen, "Improving Thai Science Teachers' TPACK through an Innovative Continuing Professional Development Program,” J. Phys. Conf. Ser., vol. 1340, no. 1, 2019, doi: 10.1088/1742-6596/1340/1/012017.

[28] T. T. Wijaya, Z. Ying and A. Purnama, "The empirical research of hawgent dynamic mathematics technology integrated into teaching,” J. Cendekia J. Pendidik. Mat., vol. 04, no. 01, pp. 144-150, 2020.

[29] T. T. Wijaya, T. Jianlan and P. Aditya, "Developing an Interactive Mathematical Learning Media Based on the TPACK Framework Using the Hawgent Dynamic Mathematics Software,” in Emerging Technologies in Computing, 2020, pp. 318-328, doi: 10.1007/978-3-030-60 036-5.

[30] M. Bernard and S. Chotimah, "Improve student mathematical reasoning ability with open-ended approach using VBA for powerpoint," AIP Conf. Proc., vol. 2014, no. September, 2018, doi: 10.1063/1.5054417. 